\title{
VECTORS of change in the marine environment: Ecosystem and economic impacts and management implications
}

\section{Introduction}

Human use of the European marine environment is increasing and diversifying. This is creating new mechanisms for human induced-changes in marine life which need to be understood and quantified as well as the impact of these changes on ecosystems, their structures (e.g. biodiversity) and functioning (e.g. productivity), and the social and economic consequences that arise. The current and emerging pressures are multiple and interacting, arising, for example, from transport, platforms for renewable and nonrenewable energy, exploitation of living and non-living resources, agricultural and industrial discharges, together with wider environmental changes (including climate change). Anticipating the future consequences of these pressures and vectors of change for marine life and of adaptation and mitigation measures (such as the introduction of new technologies and structures, new ballast water practices, ocean and offshore wind energy devices and new fishing strategies) is a prerequisite to the development and implementation of strategies, policies and regulations to manage the marine environment, such as the IMO Convention on ballast water management and the EU Maritime Policy and Marine Strategy Framework Directive.

Recognising the economic and societal importance of marine life and potential consequences of future change, the EU funded a large-scale research project, "VECTORS of Change in Oceans and Seas Marine Life, Impact on Economic Sectors" (VECTORS, www. marine-vectors.eu). The clear aim of VECTORS was to deliver genuinely integrated, interdisciplinary research. The objectives of VECTORS were to:

- Collate understanding of the different current and potential future pressures and vectors of change in the marine environment

- Advance understanding of the mechanisms of changes in marine life and the role of human activity

- Determine the impacts of changes in marine life on ecosystems, their structure and functioning, the services they provide, and the economic and societal implications

- Project the future changes and consequences of multi-sectoral human activity in the marine environment under future possible scenarios of adaptation and mitigation

- Synthesise the derived information into innovative, predictive management tools and strategies targeted to different policymakers and other stakeholders

Given the complex nature of the marine environment, its multiple stressors and ecosystem responses, it was necessary to focus on specific areas of concern. These areas were:

- Outbreaks of invasive or indigenous species

- Changes in the distribution of marine organisms, such as commercially exploited fish.

The vectors of these changes, and the related impacts on biodiversity and maritime economic sectors were considered as well as the policy and management implications. The approach was to develop generic understanding and test it through three case study regional seas (Western Mediterranean, North Sea and Baltic Sea). The natural contrasts offered by these three regions helped ensure that the VECTORS outputs are relevant and valuable to other regional seas.

The VECTORS project addressed a complex array of sectoral interests: areas of concern for marine life, regional seas, biodiversity, and academic disciplines as well as stakeholder interests. VECTORS aimed to explore, elucidate, and model links between all areas of interest, and then effectively communicate them to the relevant stakeholders. VECTORS was totally focussed on The Ecosystem Approach sensu stricto in which humans are an integral part of the ecosystem and the overall aim of marine management is to deliver ecosystem services for the benefit of society while at the same time maintaining, enhancing and protecting the natural capital of the marine environment.

\section{Integrative research in an applied context}

The VECTORS project developed integrated, multidisciplinary, research-based understanding that contributed towards the information and knowledge required for addressing forthcoming requirements, policies and regulations across multiple sectors. An integrative research approach was emphasised from the beginning of the VECTORS project and throughout. It was achieved through strong interdependency between the different research strands that often cooperatively addressed the different objectives. For example: through jointly developed scenarios used by different disciplines; through a focus on ecosystem services; through linking natural science and social science outcomes mediated by governance and social drivers as well as global change scenarios; and through development of generic research understanding that was applied and tested in regional sea contexts. A focus was maintained across all of the relevant facets of change in marine life and its consequences for different industry and public sectors in the regional seas of Europe.

VECTORS aimed to provide data, innovative models and decision support tools to relevant stakeholders within the environmental, 
policy and socio-economic spheres. To achieve this it employed a combination of policy and sector analysis, data synthesis, comprehensive statistical analysis, targeted experimentation, social and economic valuation, and ecosystem and economic modelling along with regular and in-depth stakeholder consultation and interaction. VECTORS promoted the application of its tools and knowledge throughout the lifetime of the project and beyond, aiming to seek outcomes from the research as well as outputs, culminating in the production of a synthesis website of the project's findings. More than 230 peer-reviewed papers were produced in association with this project and a representative portion of the research undertaken in VECTORS is collated within this special issue. An overview of these papers is provided here in the context of the scientific objectives of VECTORS.

\section{Scientific objectives of VECTORS}

The scientific objectives of VECTORS were highly interlinked. The research presented in the special issue and introduced here provides examples of efforts to address most of the scientific objectives:

- To review understanding of the different current and potential future pressures and vectors of change in the marine environment

Early and rapid reviews provided the contextual scene for VECTORS and enabled the project, including the papers presented in this special issue, to build upon existing work (Ojaveer et al., 2011; Defew et al., 2012).

- To elucidate mechanisms causing outbreaks of indigenous species and the spread of invasive species by transport or via other transfer vectors

VECTORS increased understanding of the ecological frames in which outbreaks are more likely to occur or invasions more likely to impact on native communities, with cascading effects on diversity and ecosystem functioning. A prerequisite to achieve this was the creation and compilation of databases such as the online information system on aquatic non-indigenous and cryptogenic species (AquaNIS, www.corpi.ku.lt/databases/index.php/aquanis). This database was designed to assemble, store and disseminate comprehensive data on organisms introduced to marine, brackish and coastal environments of Europe and neighbouring regions, and hence assist the evaluation of the progress made towards achieving biological invasion management goals (Olenin et al., 2013). The paper by Galil et al. (2018) contributed to that database for the Mediterranean Sea, identifying 726 multicellular non indigenous species (NIS), their patterns of introduction, and discussing the implications for management (including monitoring) and policy. Cardeccia et al. (2018) analysed the biological traits of sixty-eight widespread multicellular non-indigenous species identifying the traits commonly associated with these species and the functional groups that describe most of them. These 'most widespread' species comprise a wide range of taxa and biological trait profiles and a clear"identikit of a perfect invader" for marine and brackish environments is difficult to define.

Pelagia noctiluca (Forskål, 1775) (Scyphozoa) is recognised as the predominant outbreaking jellyfish species in the Western and Central Mediterranean Sea. Milisenda et al. (2018) have investigated its sexual reproduction elucidating some of its mechanisms and patterns of outbreaks formation. In the North Sea, the settlement of planula larvae of two commonly encountered jellyfish species was investigated using a combination of laboratory experiments and hydrodynamic modelling approaches. Gambill et al. (2018) found that projected warming of the North Sea will not impede the settlement of planula larvae of these species. Further application of the approaches used will improve understanding and prediction of climate-dependent changes in the production of scyphozoans and other gelatinous plankton.

- To distinguish between those mechanisms of changes in fish distribution and productivity that are caused by environmental and human-induced changes

Four broad categories of spatially-explicit modelling approaches currently used to understand and project changes in the distribution and productivity of living marine resources were reviewed and compared by Peck et al. (2018). These include: 1) statistical species distribution models, 2) physiology-based, biophysical models of single life stages or the whole life cycle of species, 3 ) food web models, and 4) end-to-end models. Teal et al. (2018) examine in greater detail two approaches for developing physiology-based models to characterize fish habitat suitability considering their strengths and limitations.

Research in VECTORS focussed on combined effects of broad scale and local drivers of change on fish distribution and productivity, particularly in the case study areas. Kanstinger et al. (2018) exemplifies this as it considers how the massive reduction in submerged macrophytes observed in recent decades in the southwest Baltic Sea, thought to have been caused by eutrophication, has affected a key location for spawning with potential ramifications for an important herring stock. Experimental and modelling approaches used by Illing et al. (2018) demonstrate that adaptive behavioural and physiological responses are tightly linked to prey match-mismatch dynamics in larval herring and that these responses can be included in models to better explore how bottomup processes regulate larval fish growth and survival. Archambault and Le Pape et al. (2018) used a life-cycle modelling approach to examine the effect of different stressors: climate variability, habitat availability and fisheries on the Eastern English Channel (EEC) population of the common sole (Solea solea). Their spatially structured age-and stage-based hierarchical Bayesian model, integrating various aspects of ecological knowledge, data sources and expert knowledge, indicated that all of these stressors can interact in important ways to influence population renewal.

- To develop a modelling framework aiming at predicting the impact of area-based restrictions on key sectors of activity

VECTORS analysed the determinants of human activities focussing particularly on the spatial interactions between fishing activities and other human uses (e.g. maritime traffic, offshore wind farms, aggregate extractions), but also the behaviour of nonfishing sectors of activity (Bastardie et al., 2013 \& 2015; Marchal et al., 2014a; b; Girardin et al., 2015; Tidd et al., 2015). VECTORS research analysed fishing decision-making processes based on existing data and then made forecasts building on scenarios. Models developed, refined and applied in VECTORS indicated that traditions (reflected by past effort allocation) and economic opportunism remain more important in driving effort allocation than spatial interactions/competition with other fishing fleets, maritime traffic, aggregate extraction, wind farms and closed areas. Model results were largely confirmed by interviews with stakeholders from different sectors of activity. Many of these studies are reviewed by Janßen et al. (2018) within the context of examining the challenges associated with the integration of fisheries into marine spatial planning. Techniques exist to analyse areas most frequently utilized by fishers, to assess the drivers for fisher's behaviour, to examine the effects of spatial competition on fisheries 
and to estimate which spaces that might become important fishing areas in the future.

\section{- To quantify the impact of changes on ecosystem structure i.e. biodiversity and ecosystem functioning}

The impact of changes in distribution and productivity of species and outbreaks of indigenous or invasive species on ecosystem structure and functioning have been quantified through a combination of systematic reviews (Bulleri et al., 2012; Rilov et al., 2012; Lyons et al., 2014) and experimental and field case studies. Bulleri et al. (2018) examined the indirect and direct mechanisms regulating shifts among alternative habitats on rocky reefs and how those mechanisms were regulated by wave-exposure and humaninduced degradation of environmental conditions. The Asian mussel Arcuatula senhousia has recently invaded the Oristano Lagoon-Gulf system in Italy but Como et al. (2018) found little evidence of impact on native assemblages or alteration of trophodynamic structure and function. The lack of impact is probably due to the low rate of invasion, which may be limited by a variety of factors. The Harris mud crab Rhithropanopeus harrisii has recently expanded into much of the Baltic Sea. In laboratory experiments Lokko et al. (2018) found that this species modifies taxonomic composition and species abundances of meiobenthic communities on unvegetated soft-bottom sediments.

\section{- To quantify the economic consequences of changes in marine ecosystems}

VECTORS considered the economic consequences of changes in marine ecosystems with respect to ecosystem services. Ecological indicators were identified for quantifying the ecosystem goods and services provided by marine ecosystems (Hattam et al., 2015a). Survey based choice experiments (Börger et al., 2014) and group based deliberative approaches (Hattam et al., 2015b) were used to estimate changes in value of ecosystem services under different scenarios that would impact on marine life. Stated preference valuation methods in particular need to be based on sound natural science information and which must be translated for use in social surveys. Using VECTORS case studies Börger et al. (2018) demonstrated the flow of information between different disciplines in the preparation and implementation of stated preference studies. They have highlighted the key opportunities and pitfalls of these studies and provided guidance to natural scientists on stated preference valuation.

- To determine the effects of changes in ecosystem services and marine resources on the economic sectors which use them

VECTORS analysed the impact of ecological changes on the economic results of different marine sectors (fisheries, aquaculture. and tourism) including key interactions between multiple uses and sectors; different strategies for mitigation and adaptation; and the incentives for international, interregional and intersectoral cooperation in managing the marine environment. Groeneveld et al. (2018a) review the current literature on the economic impacts of marine ecological change, including the published work carried out within the VECTORS project, with case studies demonstrating that the impacts of invasions and outbreaks on fisheries, aquaculture, and tourism can potentially amount to several tens of millions of dollars each year in some regions. Much of the economic analysis was undertaken in relation to scenarios that were developed by Groeneveld et al. (2018b). Their paper describes how the interdisciplinary scenarios were developed, but also explores the complexities involved including the substantial difference in time scale between societal and physical drivers.

- To provide future projections of key environmental variables and changes in marine life in response to long-term climate change and key anthropogenic drivers

Kay and Butenschön (2018) describe how biogeochemical models projections of multiple ecosystem indicators in European regional seas were generated under different future climate change and river management scenarios. They then use the projections to explore the vulnerability of marine protected areas. Their model projections were used to underpin the scenarios defined by Groeneveld et al. (2018b) and, thus, delivered the environmental conditions for the simulated scenarios to drive the modelling activities across the VECTORS project building on their lower trophic level simulations (Pinnegar et al., 2013). A vast array of different projection models were used in VECTORS and Queirós et al. (2016) demonstrated how 63 outputs, originating from 54 distinct models could be combined to produce maps collocating hot spots of ecosystem impacts of climate change with areas planned for conservation and wind farms.

- To describe and estimate quantitatively the possible future social and economic consequences implied by changes in EU Regional Seas marine ecosystems

A variety of VECTORS papers address these themes including the work of Groeneveld et al. (2018 a, b) whose scenario projections include the key socio-economic variables of Gross Domestic Product (GDP), population size, world diesel prices, and world fish prices. Using such scenarios, Groeneveld et al. (2018a) go on to demonstrate that climate-driven gradual changes in distribution and productivity of commercial fish stocks will have an impact on fisheries, although these impacts are likely to be overshadowed by much larger changes in prices of seafood and fuel.

Body burden of metals of mussels that are cultured for human and animal food in Danish waters was also considered under future scenarios by Maar et al. (2018) based on observations and modelling. Their results indicate that current EU Water Framework Directive Targets for metals are not sufficiently protective when considering the body burdens of mussels produced for human consumption. Climate change may increase metal contamination of mussels, but not to any critical level at the relatively unpolluted sites. Tomlinson et al. (2018) developed a socio-ecological model to capture the effects of changes in abundance of the Pelagia noctiluca on local fisheries, tourism and the wider economy. Scenarios of different abundance/frequency of jellyfish blooms projected significant positive and negative changes to regional gross domestic product (GDP) and employment in the Mediterranean.

- To develop and apply an integrative, cross-sectoral modelling framework that allows evaluation of the costs and trade-offs of maintaining economic activity in various sectors while protecting natural resources

Understanding and quantifying the spatial distribution of human pressures (mapping and modelling) is vital for the evaluation of trade-offs between human uses of the oceans and protection of ecosystems and the services they provide. A number of different modelling techniques have evolved in order to examine 'tradeoffs' (Peck et al., 2018) and three of these (Atlantis, Ecospace and OSMOSE) were applied within VECTORS (Pinnegar et al., 2013). The complex Atlantis model was parametrised and tuned for the Eastern English Channel by Girardin et al. (2018). The calibration process revealed the importance of coastal areas and of nutrient 
inputs from estuaries for production of two commercially exploited flatfish species, sole (Solea solea) and plaice (Pleuronectes platessa). Peck et al. (2018) concluded that continued development of end-toend models is required in order to assess how multiple pressures may interact to cause changes in living marine resources and the ecological and economic costs and trade-offs of different spatial management strategies.

- To use a synthesis of governance to produce recommendations targeted at policymakers and stakeholders

Muntadas et al. (2018) have developed a user-friendly knowledge platform to inform on the effects of bottom trawl fishing on benthic communities. The platform aims to be a deliberation support tool for fisheries' stakeholders and, simultaneously, raise public awareness of the need for good benthic community knowledge to appropriately inform 'ecosystem approach to fisheries' based management plans.

The review on the integration of fisheries into marine spatial planning (Janßen et al., 2018) identifies a wide range of challenges, including how fisheries could benefit from marine spatial planning, and provides an overview of developments on concepts, tools, and methods.

Burdon et al. (2018) advocate that sustainable management of marine systems requires integration of natural and social sciences. They describe the development and case study application in the Dogger Bank (North Sea) of an interdisciplinary framework to support the integrated management of the marine environment. The framework applies the VECTORS scenarios (Groeneveld et al., $2018 \mathrm{~b}$ ) to the assessment of environmental policy and governance; ecosystem services, indicators and valuation; modelling tools for management, and risk assessment and risk management. Burdon et al. (2018) highlight that input of local knowledge through stakeholder engagement is a necessary requirement to produce sitespecific policy recommendations.

A key vector of invasive species is the ballast water from ships. Management of ballast water is a rapidly evolving area, particularly with the global adoption of the International Convention for the Control and Management of Ships' Ballast Water and Sediments (BWM Convention) to globally harmonize action against the transfer of harmful aquatic organisms and pathogens via ships' ballast water and related sediments. Analysis of the BWM Convention requirements by David and Gollasch (2018) indicates the different steps countries need to take. They identify issues that still need to be resolved and the core theoretical and applied measures required to solve these issues, with the aim to support more efficient and coordinated implementation of the BWM Convention requirements in EU and other seas.

A key output from the VECTORS project is a synthesis website of the project's research results which can be found at http://www. marine-vectors.eu/. The synthesis website provides a tool for stakeholders, marine managers and policymakers and advisors to access VECTORS knowledge, (including a searchable, open access list of all of the publications with links to the journal website) that can be used to support marine management decisions, policies and governance.

\section{Mobilising interdisciplinary, international research expertise}

The interdisciplinary VECTORS project mobilised expertise across Europe, integrating a critical mass of marine ecologists, fisheries scientists, statisticians, system modellers, economists, environmental economists and cultural anthropologists. These were experts in marine ecosystems, fisheries, maritime transport, tourism and coastal development, and included those involved in policy support roles (e.g. through CIESM, EU, HELCOM, ICES, IMO, OSPAR). Their combined effort enable VECTORS research to respond to the multiple drivers affecting the marine environment, the multi-sectoral impacts on marine life, and the resulting ecosystem and economic impacts, from an end-to-end perspective. Many of the papers in this issue exemplify that interdisciplinary approach (e.g. Börger et al., 2018; Janßen et al., 2018; Groeneveld et al., 2018a,b; Burdon et al., 2018; David and Gollasch, 2018).

\section{Research that supports policy}

The EU's overarching policy, aimed at developing a thriving maritime economy in an environmentally sustainable manner, needs to be supported by excellent marine scientific research. An impact of VECTORS has been to deliver integrated marine and maritime research in support of the various EU and international maritime and marine policies, Directives and other legislation. VECTORS addressed system complexity and interactions through enhanced integration of knowledge and research. It bridged boundaries between science and policy-making, scientific disciplines and industrial sectors. The VECTORS project approach sought to support new forms of governance by seeking consensus among all concerned parties and establishing continuous dialogue throughout the project particularly between scientists and policymakers but also industry sector stakeholders and representatives from society.

\section{Conclusions}

VECTORS followed an inter-disciplinary and multi-sectorial approach with research directly addressing policy and management needs, particularly in support of the EU's Marine Strategy Framework Directive (MFSD), Integrated Maritime Policy (IMP), Common Fisheries Policy (CFP), Alien Invasive Species Directive and the EU implementation of the IMO Ballast Water Management Convention. Ultimately, the success of the VECTORS project, reflected in this collation of papers, arose from the recognition from the planning and very beginning of the project that the key research driver was the need to provide support for international policy, legislation and management that included:

- Better assessment of the impacts of climate change on oceans and on coastal areas

- Improved understanding of the impact of human activities on coastal and marine ecosystems and their management, including mitigation of the cumulative effects of maritime activities

- Tools and understanding to support implementation of an ecosystem approach to resource management and spatial planning and help optimise the management of marine and maritime activities and their sustainable development

- More knowledge on the functional role of marine biodiversity, and its evolution, protection and exploitation

- Further advancement in the development of operational oceanography, with a view to improving prediction on the sea state and dynamics, assessment of risks and

- Support for decision making and the conciliation of competing interests in marine and coastal areas in pursuit of sustainable exploitation of ecosystems and delivery of goods and services through the activities of a variety of marine and maritime sectors. 


\section{Acknowledgements}

The research leading to these results has received funding from the European Community's Seventh Framework Programme (FP7/ 2007-2013) under Grant Agreement No. [266445] for the project Vectors of Change in Oceans and Seas Marine Life, Impact on Economic Sectors (VECTORS).

We are grateful for the support and efforts of all of our colleagues in VECTORS, particularly the other Workpackage leaders and Steering Committee Members: Anne Sell, Caroline Hattam, Erik Buisman, Paul Marchal, Henn Ojaveer, Dolors Blasco, Francesc Maynou, Margit Eero, John Pinnegar, Francesco Bosello, Paolo Magni, Sharon Tatman, Rolf Groeneveld, Daryl Burdon, Paulo Nunes, Paolo Domenici; our Project Manager Jenny Lockett; and of course all of the authors who contributed their research papers to this special issue.

\section{References}

Archambault, B., Rivot, E., Savina, M., Le Pape, O., 2018. Using a spatially structured life cycle model to assess the influence of multiple stressors on an exploited coastal-nursery-dependent population. Estuar. Coast Shelf Sci. 201, 95-104.

Bastardie, F., Nielsen, J.R., Miethe, T., 2013. DISPLACE: a dynamic, individual-based model for spatial fishing planning and effort displacement - integrating underlying fish population models. Can. J. Fish. Aquat. Sci. 71 (3), e386, 366. https:// doi.org/10.1139/cjfas-2013-0126.

Bastardie, F., Nielsen, J.R., Eigaard, O.R., Fock, H.O., Jonsson, P., Bartolino, V., 2015. Competition for marine space: modelling the Baltic Sea fisheries and effort displacement under spatial restrictions. ICES J. Mar. Sci. 72, ee840, 824. https://doi.org/10.1093/icesjms/fsu215.

Börger, T., Böhnke-Henrichs, A., Hattam, C., Piwowarczyk, J., Schasfoort, F., Austen, M.C., 2018. The role of interdisciplinary collaboration for stated preference methods to value marine environmental goods and ecosystem services. Estuar. Coast Shelf Sci. 201, 140-151.

Börger, T., Hattam, C., Burdon, D., Atkins, J.P., Austen, M.C., 2014. Valuing conservation benefits of an offshore marine protected area. Ecol. Econ. 108, 229-241.

Bulleri, F., Cucco, A., Dal Bello, M., Maggi, E., Ravaglioli, C., Benedetti-Cecchi, L., 2018. The role of wave exposure and human impacts in regulating the distribution of alternative habitats on NW Mediterranean rocky reefs. Estuar. Coast Shelf Sci. 201, 114-122.

Bulleri, F., Mant, R.C., Benedetti-Cecchi, L., Chatzinikolaou, E., Crowe, T.P., Kotta, J., Lyons, D.A., Rilov, G., Maggi, E., 2012. The effects of exotic seaweeds on native benthic assemblages: variability between trophic levels and influence of background environmental and biological conditions. Environ. Evid. 1 (1), 8. http:// www.environmentalevidencejournal.org/content/1/1/8.

Burdon, D., Boyes, S.J., Elliott, M., Smyth, K., Atkins, J.P., Barnes, R.A., Wurzel, R.K., 2018. Integrating natural and social sciences to sustainably manage vectors of change in the marine environment: dogger bank transnational case study. Estuar. Coast Shelf Sci. 201, 234-247.

Cardeccia, A., Marchini, A., Occhipinti-Ambrogi, A., Galil, B., Gollasch, S., Minchin, D., Narščius, A., Olenin, S., Ojaveer, H., 2018. Assessing biological invasions in European seas: biological traits of the most widespread non-indigenous species. Estuar. Coast Shelf Sci. 201, 17-28.

Como, S., Floris, A., Pais, A., Rumolo, P., Saba, S., Sprovieri, M., Magni, P., 2018. Assessing the impact of the Asian mussel Arcuatula senhousia in the recently invaded Oristano Lagoon-gulf system (W Sardinia, Italy). Estuar. Coast Shelf Sci. 201, 123-131.

David, M., Gollasch, S., 2018. How to approach Ballast water management in European seas. Estuar. Coast Shelf Sci. 201, 248-255.

Defew, E.C., Paterson, D.M., Blight, A. (Eds.), 2012. Direct and Indirect Pressures for Change in European Regional Seas. VECTORS Deliverable 1.2 p.390. www. marine-vectors.eu/Deliverables_en.

Galil, B.S., Marchini, A., Occhipinti-Ambrogi, A., 2018. East is East and West is West? Management of marine bioinvasions in the Mediterranean sea. Estuar. Coast Shelf Sci. 201, 7-16.

Gambill, M., McNaughton, S.L., Kreus, M., Peck, M.A., 2018. Temperature-dependent settlement of planula larvae of two scyphozoan jellyfish from the North sea. Estuar. Coast Shelf Sci. 201, 64-71.

Girardin, R., Fulton, E.A., Lehuta, S., Rolland, M., Thébaud, O., Travers-Trolet, M., Vermard, Y., Marchal, P., 2018. Identification of the main processes underlying ecosystem functioning in the Eastern English Channel, with a focus on flatfish species, as revealed through the application of the Atlantis end-to-end model. Estuar. Coast Shelf Sci. 201, 208-222.

Girardin, R., Vermard, Y., Thébaud, O., Tidd, A., Marchal, P., 2015. Predicting Fisher response to competition for space and resources in a mixed demersal fishery. Ocean Coast Manag. 106, e135, 124. https://doi.org/10.1016/j.ocecoaman.2015. 01.017.

Groeneveld, R.A., Bartelings, H., Börger, T., Bosello, F., Buisman, E., Delpiazzo, E.,
Eboli, F., Fernandes, J.A., Hamon, K.G., Hattam, C., Loureiro, M., Nunes, P.A.L.D., Piwowarczyk, J., Schasfoort, F.E., Simons, S.L., Walker, A.N., 2018a. Economic impacts of marine ecological change: review and recent contributions of the VEC TORS project on European marine waters. Estuar. Coast Shelf Sci. 201, 152-163. Groeneveld, R.A., Bosello, F., Butenschön, M., Elliott, M., Peck, M.A., Pinnega, J.K., 2018b. Defining scenarios of future vectors of change in marine life and associated economic sectors. Estuar. Coast Shelf Sci. 201, 164-171.

Hattam, C., Atkins, J.P., Beaumont, N.J., B rger, T., B hnke-Henrichs, A., Burdon, D., de Groot, R., Hoefnagel, E., Nunes, P.A.L.D., Piwowarczyk, J., Sastre, S., Austen, M.C. 2015a. Marine ecosystem services: linking indicators to their classification. Ecol. Indicat. 49, 61-75.

Hattam, C., B hnke-Henrichs, A., B rger, T., Burdon, D., Hadjimichael, M., Delaney, A., Atkins, J.P., Garrard, S., Austen, M.C., 2015b. Integrating methods for ecosystem service assessment and valuation: mixed methods or mixed messages? Ecol. Econ. 120, e138, 126. https://doi.org/10.1016/j.ecolecon.2015.10.011.

Illing, B., Moyano, M., Berg, J., Hufnagl, M., Peck, M.A., 2018. Behavioural and physiological responses to prey match-mismatch in larval herring. Estuar. Coast Shelf Sci. 201, 82-94.

Janßen, H., Bastardie, F., Eero, M., Hamon, K.G., Hinrichsen, H.-H., Marchal, P., Nielsen, J.R., Le Pape, O., Schulze, T., Simons, S., Teal, L.R., Tidd, A., 2018. Integration of fisheries into marine spatial planning: Quo Vadis? Estuar. Coast Shelf Sci. 201, 105-113.

Kanstinger, P., Beher, J., Grenzdörffer, G., Hammer, C., Huebert, K.B., Stepputis, D. Peck, M.A., 2018. What is left? Macrophyte meadows and Atlantic herring (Clupea harengus) spawning sites in the Greifswalder Bodden, Baltic sea. Estuar. Coast Shelf Sci. 201, 72-81.

Kay, S., Butenschön, M., 2018. Projections of change in key ecosystem indicators for planning and management of marine protected areas: an example study for European seas. Estuar. Coast Shelf Sci. 201, 172-184.

Lokko, K., Kotta, J., Orav-Kotta, H., Nurkse, K., Pärnoja, M., 2018. Introduction of a functionally novel consumer to a low diversity system: effects of the mud crab Rhithropanopeus harrisii on meiobenthos. Estuar. Coast Shelf Sci. 201 $132-139$.

Lyons, D.A., Arvanitidis, C., Blight, A.J., Chatzinikolaou, E., Guy-Haim, T., Kotta, I., Orav-Kotta, H., Queiros, A.M., Rilov, G., Somerfield, P.J., Crowe, T.P., 2014. Macroalgal blooms alter community structure and primary productivity in marine ecosystems. Global Change Biol. 20 (9), e2724, 2712. https://doi.org/10.1111/ gcb.12644.

Maar, M., Larsen, M.M., Tørring, D., Petersen, J.K., 2018. Bioaccumulation of metals $(\mathrm{Cd}, \mathrm{Cu}, \mathrm{Ni}, \mathrm{Pb}$ and $\mathrm{Zn})$ in suspended cultures of blue mussels exposed to different environmental conditions. Estuar. Coast Shelf Sci. 201, 185-197.

Marchal, P., Bartelings, H., Bastardie, F., Batsleer, J., Delaney, A., Girardin, R. Gloaguen, P., Hamon, K.G., Hoefnagel, E., Jouanneau, C., Mah evas, S. Nielsen, J.R., Piwowarczyk, J., Poos, J.J., Schulze, T., Rivot, E., Simons, S., Tidd, A., Vermard, Y., Woillez, M., 2014a. Mechanisms of Change in Human Behaviour. VECTORS Deliverable 2.3.1. http://www.marine-vectors.eu/ deliverables/D2_3_1.pdf. last accessed: 26.10.20175.

Marchal, P., Desprez, M., Vermard, Y., Tidd, A., 2014b. How do demersal fishing fleets interact with aggregate extraction in a congested sea? Estuar. Coast Shelf Sci. 149, 168-177.

Milisenda, G., Martinez-Quintana, A., Fuentes, V.L., Bosch-Belmar, M., Aglieri, G. Boero, F., Piraino, S., 2018. Reproductive and bloom patterns of Pelagia noctiluca in the strait of Messina, Italy. Estuar. Coast. Shelf Sci. 201, 29-39.

Muntadas, A., Lample, M., Demestre, M., Ballé-Béganton, J., de Juan, S., Maynou, F. Bailly, D., 2018. A knowledge platform to inform on the effects of trawling on benthic communities. Estuar. Coast Shelf Sci. 201, 223-233.

Ojaveer, H., Austen, M., Beare, D., David, M., Dominici, P., Kraus, G.L., Lockett, J. Paterson, D.M., Pinnegar, J., Pi nol, L., Rodríguez, L., Sell, A., Sastre Sanz, S., 2011. Review of Regional Seas Vectors and Drivers. VECTORS Deliverable 1.1 p.222. www.marine-vectors.eu/Deliverables_en.

Olenin, S., Narçius, A., Minchin, D., David, M., Galil, B.S., Gollasch, S., Marchini, A. Occhipinti-Ambrogi, A., Ojaveer, H., Zaiko, A., 2013. Making non-indigenous species information systems practical for management and useful for research: an aquatic perspective. Biol. Conserv. 173, e107, 98. https://doi.org/10.1016/j. biocon 2013.07.040. https://doi.org/10.1016/j.biocon.2013.07.040.

Peck, M.A., Arvanitidis, C., Butenschön, M., Canu, D.M., Chatzinikolaou, E., Cucco, A., Domenici, P., Fernandes, J.A., Gasche, L., Huebert, K.B., Hufnagl, M., Jones, M.C. Kempf, A., Keyl, F., Maar, M., Mahévas, S., Marchal, P., Nicolas, D., Pinnegar, J.K., Rivot, E., Rochette, S., Sell, A.F., Sinerchia, M., Solidoro, C., Somerfield, P.J. Teal, L.R., Travers-Trolet, M., van de Wolfshaar, K.E., 2018. Understanding and projecting changes in the distribution and productivity of living marine resources: a critical review of modelling approaches. Estuar. Coast Shelf Sci. 201, 40-55.

Pinnegar, J.K., Jones, M., Keyl, F., Sell, A., Kempf, A., Cheung, W.W.L., Cucco, A., Sinerchia, M., Marras, S., Domenici, P., Teal, L., Maar, M., Møller, E.F., Hufnagl, M., Kreus, M., P€atsch, J., Peck, M., Diekmann, R., Lorkowski, I., M €ollmann, C., Temming, A., LeQuesne, W.J., 2013. Future Distribution and Productivity of Marine Fish and Invertebrates. VECTORS Deliverable 5.1.2, p. 92 www.marine-vectors.eu/Deliverables_en.

Queiros, A., Huebert, K., Keyl, F., Fernandes, J., Stolte, W., Maar, M., Kay, S., Jones, M. Teal, L., Hamon, K., Hendriksen, G., Vermard, Y., Marchal, P., Somerfield, P., Austen, M., Barange, M., Sell, A., Allen, J.I., Peck, M.A., 2016. Solutions for ecosystem-level protection of ocean systems against climate change. Global Change Biol. 22, e3936, 3927. https://doi.org/10.1111/gcb.13423/full.

Rilov, G., Mant, R.C., Lyons, D.A., Bulleri, F., Benedetti-Cecchi, L., Kotta, J., 
Queiros, A.M., Chatzinikolaou, E., Crowe, T.P., Guy-Haim, T., 2012. How strong is the effect of invasive ecosystem engineers on the distribution patterns of local species, the local and regional biodiversity and ecosystem functions? Environ. Evid. 1 (1), 10. http://www.environmentalevidencejournal.org/content/1/1/10.

Teal, L.R., Marras, S., Peck, M.A., Domenici, P., 2018. Physiologically-based modelling approaches to characterize fish habitat suitability: their usefulness and limitations. Estuar. Coast Shelf Sci. 201, 56-63.

Tidd, A.N., Vermard, Y., Marchal, P., Pinnegar, J.K., Blanchard, J.L., MilnerGulland, E.J., 2015. Fishing for space: fine-scale multi-sector maritime activities influence Fisher location choice. PLoS One 10 (1), e0116335. https://doi.org/10 1371/journal.pone.0116335.

Tomlinson, B., Maynou, F., Sabatés, A., Fuentes, V., Canepa, A., Sastre, S., 2018. Systems approach modelling of the interactive effects of fisheries, jellyfish and tourism in the Catalan Coast. Estuar. Coast Shelf Sci. 201, 198-207.

M.C. Austen*

Plymouth Marine Laboratory, Prospect Place, Plymouth PL1 3DH, UK

T.P. Crowe

School of Biology \& Environment Science, University College Dublin, Science Centre - West Belfield, Dublin 4, Ireland

M. Elliott

Institute of Estuarine \& Coastal Studies, University of Hull, Hull, HU6

$7 R X, U K$
D.M. Paterson

Scottish Oceans Institute, School of Biology, University of St Andrews, St Andrews, Fife, KY16 8LB, UK

M.A. Peck

Institute of Hydrobiology and Fisheries Science, Center for Earth System Research and Sustainability, University of Hamburg, Olbersweg 24, D-22767 Hamburg, Germany

S. Piraino

Dipartimento di Scienze e Tecnologie Biologiche ed Ambientali (DiSTeBA), University of Salento, Lecce, Italy

Consorzio Nazionale Interuniversitario per le Scienze del Mare (CoNISMa), Rome, Italy

${ }^{*}$ Corresponding author. E-mail address: mcva@pml.ac.uk (M.C. Austen). 